\title{
Compensating Nuclear Weapons Workers and Their Survivors: The Case of Fernald
}

\author{
Patricia K. Cianciolo, $\mathrm{PhD}$ \\ Northern Michigan University
}

* Please address correspondence to Patricia K. Cianciolo, Northern Michigan University, Social Work Department, 1401 Presque Isle Avenue, Marquette, MI 49855. Email: pciancio@nmu.edu.

\begin{abstract}
Nuclear power plant disasters in recent history have had significant global, environmental, health, and social consequences. Compensation systems have been designed and are required by plants that have had such disasters to mitigate the risks and deleterious effects of the industry world-wide. The large-scale production of nuclear weapons that occurred in the United States during the Cold War also created additional consequences for plant workers, their families, and the communities where facilities were located. The Energy Employees Occupational Illness Compensation Act (EEOICPA) was legislated by Congress in 2000 to remunerate workers and/or their survivors for risks associated with exposure while employed. Fernald, located northwest of Cincinnati, Ohio, was the location of one of several hundred plant facilities throughout the U.S. that aided in nuclear weapons production. This small exploratory case study examined how former Fernald workers and their family members experienced the legal application and/or determination process in order to receive compensation for past risks. Social justice implications are discussed in the conclusions, as well as directions for future research.
\end{abstract}

Keywords: nuclear weapons, plant workers, occupational illness, qualitative research, EEOICPA, compensation, Fernald

\section{Introduction}

Environmental disasters, both natural and man-made, have become part of the world's lexicon in the late $20^{\text {th }}$ and early $21^{\text {st }}$ centuries. The global arms race, over-reliance on fossil fuels, increased use of nuclear power for energy needs, and climate change provide the backdrop for some of the most well-known global disasters of our time. These events have had significant long-term environmental, health, and psychological consequences for the communities 
where they have occurred. Without question, there will be a marked increase in these kinds of calamities in the decades to come.

A few of the most widely publicized nuclear power plant disasters in recent history are Three Mile Island in the United States (March, 1979), Chernobyl in the Ukraine (April, 1986), and Fukushima Daiichi in Japan (March, 2011). The first two events were due to technological and human error (Nuclear Energy Institute, 2014; World Health Organization, 2006), and the third as a result of an earthquake and massive tsunami that overwhelmed the reactors at the Japanese plant, although there is evidence that technological problems had long been present (Anzai, Ban, Ozawa, \& Shinji, 2012; Soble, 2015). Workers bore the most direct exposure risk in the accidents and, in the aftermath, clean-up workers. Radiation emissions into the atmosphere necessitated a prompt public health response to all events. In the case of Three Mile Island, evacuation of residents was optional and short lived, focusing on pregnant women and children within a five-mile radius of the plant (Bromet, Parkinson, \& Dunn, 1990). Radioactive emissions at the Chernobyl and Fukushima Daiichi plants covered a much larger geographic area, leading to massive evacuations with permanent relocation for thousands of families (Anzai et. al., 2012; Samet \& Chanson, 2015; World Health Organization, 2006).

Monetary compensation was made available for lost wages and property devaluation around Three Mile Island through a federal law passed in 1957, known as the Price-Anderson Act. This Act requires nuclear power plants to carry substantial risk insurance due to the extensive damage and hardship a nuclear accident precipitates. Compensation for health-related illnesses has been more complicated for claimants, requiring an additional level of proof (Center for Insurance Policy and Research, 2015; Center for Nuclear Science and Technology Information, 2005). Japan has adopted a similar compensation model and substantiation for health related claims by workers, clean-up workers, their families and residents remains equally arduous (Anzai et. al., 2012; Soble, 2015). The Ukraine requires nuclear power plants to hold liability insurance as well, and similar to the U.S. and Japan, proving causation for the development of a health related illness requires extensive documentation (Wesolowski, 2015; World Health Organization, 2006). Private companies owned and operated the nuclear plants in the U.S. and Japan, whereas Chernobyl was a governmental run entity.

Exposure to radiation and toxic chemicals is insidious, and the long-term environmental, health, and psychological consequences take time to manifest (Biddle, 2012; Greene, 1999; Makhijani, 2001). Nuclear weapons workers in the United States were exposed to radioactive and noxious materials over long periods of time without their knowledge during the Cold War. These "Cold War Patriots" (www.coldwarpatriots.org) sacrificed health and life not on battlefields, but in plants producing nuclear weapons, doing what they thought was their patriotic duty for their country. In 2000, President Clinton signed Executive Order 13179 - Providing Compensation for America's Nuclear Weapons Workers, establishing the Energy Employees Occupational Illness Compensation program (EEOICPA). The goal of the EEOICPA was to help plant workers and their survivors receive some compensation for their patriotic duty. The focus of 
this qualitative case study was to explore how family survivors of workers at the Fernald, Ohio, nuclear weapons facility experienced the legal application and determination process in order to receive monetary compensation from the EEOICPA program. One of over 350 facilities in the U.S., Fernald ceased production in 1989, and the area where it once operated is now a nature preserve. I provide additional background on the Fernald plant facility and community below.

\section{Background}

There is little obvious trace that Fernald, a uranium processing plant, existed. The facility and surrounding acreage was declared a federal Superfund site in 1996, with a $\$ 4.4$ billion dollar clean-up cost (Willette, 1990). The site is now referred to as a nature park boasting wetlands, prairie, and woodland areas (Maag, 2006; O’Farrell, 2006). The U.S. Interior Department has recently proposed making other high profile weapons' sites into national parks, including Los Alamos, Hanford, and Oak Ridge (Clausing, 2013).

For many Americans, knowledge about the scope of nuclear weapons production during the Cold War is limited. Even the communities where facilities were located had little knowledge of what was taking place in their own backyards (Makhijani, 2001; Sheak \& Cianciolo, 1993). The Fernald facility (Fernald) was built on 1,050 acres in the rural farming community of Ross and Crosby townships (U.S. Environmental Protection Agency, 2010; Fernald Preserve Museum, June 12, 2013). Fernald was located approximately twenty miles northwest of Cincinnati, Ohio. Like so many other facilities, the Fernald complex was self-contained and offered competitive wages and benefits, and provided important local support services (Cincinnati Times Star, 1951; Cincinnati Enquirer, 1957; Gallagher, 1993; Kiernan, 2013; Nesbit, 2014). Weapons production required access to large amounts of water for processing of materials and, out of necessity, was situated near major rivers. The Great Miami River was Fernald's water source, which sustained a huge aquifer that has and continues to supply drinking water to local residents, as well as to the Greater Cincinnati area. Also known as the Feed Materials Production Center, Fernald's unique contribution to the nuclear arsenal was the processing of high grade uranium ore. This "feed material” was transformed into ingots inserted into nuclear reactors at the Hanford and Savannah River plants. For every one pound of uranium processed, 2.2 pounds of waste was produced. A 226-acre area of the Great Miami Aquifer was contaminated, waste pits with toxic sludge were created, 31 million pounds of uranium product stored, and 2.6 million cubic yards of contaminated soil amassed. This was Fernald's environmental legacy (Fernald Preserve Museum, June 12, 2013; Thorp, 2011; U.S. Environmental Protection Agency, 2010).

Threats of communism, heightened civil defense, and the perceived need for fallout shelters bolstered U.S. nuclear armament. Even a cursory view of safety equipment used by Fernald workers illustrated gaping inadequacies from the start. Production often involved reproduction of laboratory experiments with uranium and other radioactive materials that were hypothetical in the plant setting. 
During my visit to the Fernald Museum for this study, workers interviewed for exhibits stressed this:

Sam Audia, Site Manager 1951 - 1981: is quoted about dealing with the volatility of uranium and other hazardous chemicals and materials: "Uranium could spontaneously ignite... workers were providing new ideas from all over the plant."

Lou Levy, Operations Superintendent Plant 91953 - 1983: discussed the unfamiliarity and lack of training workers had to handle all materials coming into the plant: "We had to be innovative on the job...especially when handling thorium - at least handling chemical processing around uranium was a bit more known."

Bob Gardner, Senior Operations 1953 - 1993: talked about dangers to workers: "Hazardous chemicals were the most dangerous" (e.g., nitric acid, sodium hydroxide, tributyl phosphate, trichlorethelene) (Fernald Preserve Museum, June 12, 2013).

Employees were given routine medical exams at the plant health center including chest x-rays, urinalyses, blood samples, and blood pressure screenings. Workers were obliged to shower and change clothes daily before leaving the facility in areas referred to as the "clean" and "dirty" rooms. Production workers were required to wear white caps, overhauls, and dosimetry badges to register radiation exposure levels. I met a former worker and his family while visiting the museum. As his family went through the exhibits I would hear him say, "I worked with that guy; I knew that guy." This individual had worked at Fernald for 17 years between 1970 and the late 1980s. I told him about my research and he explained, "When plutonium was coming onto the site, nobody really knew how to deal with it." He went on to say that he worries about what exposure might have done to him: "I'm alright now, but it takes a while for this stuff to show up." Employed in a similar industry in Oklahoma, he acknowledged uncertainty about the long-term health consequences of his occupation, and what the future might hold for his family if he were to become ill (Fernald Preserve Museum, June 12, 2013).

The U.S. government had been working on the development of nuclear weapons since the late 1930s. When the "radiation genie" was unleased with the Manhattan Project, the realization that atomic weapons posed dire consequences for the human species and the environment was no longer speculative (Biddle, 2012; Monk, 2012). The race to build the bomb superseded both ethical questions and cautionary warnings by scientists. The health effects of exposure to radioactive isotopes were known as early as the 1930s, and "tolerable dosages" had been identified in both medical and military settings. Data on health ramifications was intentionally dismissed or stifled, and researchers were often silenced or pressured to misrepresent their own findings (Greene, 1999; Welsome, 1999: 43-57). Western states and communities were especially vulnerable to radiations' effects due to prolific atmospheric testing and uranium mining (Dawson, 1992; Gallagher, 1993). 
Dr. Alice Stewart's collaborative work on the Oxford Study of Childhood Cancer became an important benchmark regarding the biological effects of radiation in humans. In the 1960s, research conducted by Dr. Thomas Mancuso showed elevated cancer rates with long latency periods among nuclear weapons workers at the Hanford Reservation facility. This particular study had been commissioned by the U.S. Atomic Energy Commission (AEC), and its findings were controversial. The AEC's formal position was that nuclear weapons workers were no more likely to develop cancer(s) than those working in other industries, and that industry standards were safe. It maintained a similar stance regarding the long term cancer effects of radiation exposure on Japanese citizens impacted by the atomic bombs dropped in 1945 (Greene, 1999, pps.113-127). Clothed in the secrecy of the U.S. government, experiments and the construction of new facilities to support the weapons effort continued at an accelerated and alarming pace. By the 1970s, Cold War rhetoric about communism and nuclear deterrence was beginning to unravel. Some workers, their families, and community members living near existing plants began efforts to challenge the federal government and the indemnified corporations operating the plants. A substantial body of literature had accumulated regarding the negative health consequences of nuclear weapons production on workers and surrounding communities. However, at first, the government and its contractors systematically denied the findings in this literature (Cable, Shriver \& Mix, 2008; Flynn, 2001; Mix \& Shriver, 2007; Roe, 1999; Sheak \& Cianciolo, 1993; Warrick, 1999).

The Fernald facility was catapulted into the national limelight in 1984, by two pivotal events. First, the Department of Energy (DOE), which succeeded the AEC, and the plant operator National Lead of Ohio (NLO), acknowledged that 300 pounds of enriched uranium oxide had been released into the air from a malfunctioning dust collector in Plant 9. The second event was the admission by the DOE that it had known that three water wells located south of the plant had been contaminated with uranium since 1981 (Fernald Preserve Museum, June 12, 2013; Office of Legacy Management, 2014). A group of concerned citizens, including the families whose wells were contaminated, organized a group known as Fernald Residents for Environmental Safety and Health (FRESH) the same year. This group was successful in developing a broad-based network of support to champion their cause. Many Fernald workers were hesitant to embrace FRESH's efforts at first due to employment issues, concerns about their own health, and loyalty to the government (Sheak \& Cianciolo, 1993). Community members filed a class action suit with the Cincinnati legal firm, Waite, Schneider, Bayless and Chesley, in 1984, and won in 1989. The DOE agreed to pay $\$ 78$ million dollars for emotional distress and property devaluation, and medical monitoring (Office of Legacy Management, 2014). In 1990, Fernald workers also filed their own suit with the same legal firm, and won in 1994. The worker's settlement, the first of its kind, called for \$20 million dollars for emotional distress related to increased cancer risks and lifetime medical monitoring (Cohen, 1994; New York Times, 1994; L. Roselle \& P. DeMarco, personal interview, August 27, 2013). Federal compensation programs were yet to come, however. 
On the national level, workers and family members continued their fight to secure remuneration for the risks they or their loved one(s) had experienced. State worker's compensation programs were proving to be woefully inadequate. In many instances states were in collusion with the DOE, and were systematically denying workers' claims in hopes to stave off the impending deluge (Makhyani, 2001). In the fall of 2000, Clara Harding, the widow of Joe Harding, a former uranium processing worker at the Paducah plant in Kentucky, testified before the U.S. House Judiciary Committee on Immigration and Claims. She had been battling Union Carbide, the company that managed that facility for 30 years, because of her husband's work-related illness and death. She had not received any compensation (including his pension) since his death from multiple cancers in 1980 (Flynn, 2001, p.39).

The U.S. Senate had voted in favor of a program to compensate nuclear weapons workers earlier in 2000, passing the 2001 Defense Authorization Bill, but the House was stalling (Flynn, 2001). Cost and fear of inexhaustible entitlement were the political stumbling blocks. Bill Richardson, Energy Secretary at the time, had publicly stated that the U.S. government owed these workers and their families for their loyalty and work during the Cold War (Flynn, 2001). After passing both the House and Senate, President Clinton signed Executive Order 13179 - Providing Compensation for America's Nuclear Weapons Workers, which established the Energy Employees Occupational Illness Compensation program (EEOICPA) (Executive Order 13179, 2000; Flynn, 2001, p.41; U.S. Department of Labor, n.d.). Passage of the EEOICPA was the federal government's admission that the "Cold War Patriots" had indeed been unwittingly exposed to radioactive and chemical materials that shortened their lives and caused undue suffering. Families, who either stood by to care for or lost their loved ones due to cancers caused by this exposure became members of a unique club, an unwelcomed membership: survivors of nuclear weapons workers. The legislation, although a victory for workers and their families, has not been a panacea, however, and this is partially what I focus on in this qualitative study.

The EEOICPA program is administered by the U.S. Department of Labor (DOL) and includes a number of parts (http://www.dol.gov/owcp/energy/). Only two will be discussed here. Part B is for workers and/or their survivors (effective July 31, 2001) and Part E, also for workers and survivors, addresses lost wages due to illness before retirement (effective October 28, 2004). Under Part B, workers can receive a lump sum payment of $\$ 150,000$ and medical care if they have one of 22 designated cancers, chronic beryllium disease, or for certain workers who have developed chronic silicosis. If the worker is deceased, their immediate survivors are eligible for the same lump sum without medical benefits. Part E offers varying levels of compensation due to wage loss or impairment to workers, and to their survivors with specific stipulations (for eligibility requirements see U.S. Department of Labor, Office of Workers' Compensation Programs, Division of Energy Employees Occupational Illness Compensation - Program Benefits http://www.dol.gov/owcp/energy/regs/compliance/progbenefits.htm). As of September 2012, the total compensation spent for both Part B and E (for workers and survivors, including medical expenses for workers with a designated illness 
who were still living) was almost $\$ 9$ billion dollars (U.S. Department of Labor, 2012a).

Some facilities covered by the legislation were designated as "special exposure cohorts” (SEC) (Flynn, 2001). This meant that if workers developed or died from a specified cancer, proof of causation was assumed to be the workplace. Some facilities were not SEC-designated, placing the onus of proof on the worker and their families. These individuals were required to gather all employmentrelated information to substantiate their claim - where, when, and in what capacity the employee worked in the facility, along with causation of death. This information was then examined by the National Institute of Occupational Health and Safety (NIOSH) experts to reconstruct the level of radiation exposure, known as "dose reconstruction." Fernald did not receive SEC designation until 2012, and the SEC status only covers workers who were employed during the period from January 1, 1968, through December 31, 1978; some former contractors are also covered, however (U.S. Department of Labor, 2012b). For any other workers and their families, establishing causation of illness or death remained squarely on their shoulders. For workers who do not have a "designated cancer," their life's monetary worth remains in the abyss - sick and suffering - and wondering, was my sickness or my loved ones' caused by exposure? For surviving family members there is also the nagging question of their own health. Could there be connections with familial illnesses that stem from being an offspring of a nuclear weapons worker or having lived in the same household and unknowingly been exposed oneself? Some studies suggest that this is highly probable (Anthes, 2010; Brown, et.al., 2004; Internlandi, 2013; Physicians for Social Responsibility, 2014; Roff, 1999; Roman, et.al., 1999; Schetter, 2011).

Communities where weapons facilities have been located understand that they, too, remain vulnerable. Environmental and health consequences that have been documented include contaminated ground water supplies, elevated breast cancer incidences, and higher rates of autoimmune disorders (Biddle, 2012; Gallagher, 1999; University of Cincinnati Academic Health Center, 2012; Wones et. al., 2009). In the end, the secrecy surrounding nuclear weapons production wielded a triple-edged sword. It imperiled workers, their families, and the communities where facilities were located, unmistakably altering the life course of all individuals and communities involved.

\section{Methodology}

Qualitative research methods were used to collect and analyze data, and the author was granted a one-semester sabbatical to undertake the research project. Purposive sampling was employed as a means to recruit participants (Berg, 2001; Hilton \& DeJong, 2010). Grounded Theory (Denzin \& Lincoln, 2005), and Constructed Grounded Theory (Charmaz, 2005; 2006; Creswell, 2007; Puddephatt, 2006) were used as theoretical frameworks for data analysis. The latter orientation allows the researcher to construct meaning from the data itself, thus becoming a "method and product of inquiry" and encourages "simultaneous data collection and analysis" (Charmaz, 2005, p.507). Studies that involve health concerns, financial matters, or stigmatization make recruiting participants a 
challenge. Saturation and sample size are less of a constraint for the qualitative researcher investigating sensitive topics because the primary goal of this type of inquiry resides in finding meaning not in making broad generalizations (Mason, 2010, p.1). It is especially important when researching topics with social justice implications, because it gives voice to and empowers those who have in some way been treated unfairly. Social justice incorporates ideas related to a just and democratic world, preventing wrongdoing and righting it when it occurs, and designing social policies that consider the human condition paramount (Charmaz, 2005, p.510; Rawls, 1999).

Seven in-depth, audio-recorded interviews were completed between June, 2013, and October, 2013, each lasting one to one and a half hours. The age range of participants was between 55 and 93 years old. The characteristics of participants interviewed were as follows: one child of a deceased Fernald worker who was a short-term Fernald worker himself and received compensation through the EEOICPA program because of his father's employment; another adult child of a deceased worker who was still in the claims process; two former Fernald chemical engineers, one of whom was in management and the other who was a plant supervisor. The plant supervisor had received EEIOCPA compensation as a worker, and the one in management applied but was denied. Two lawyers who had been involved in the residents' lawsuit and the Fernald workers settlement were interviewed, as well as one occupational health physician who headed up the Fernald Medical Monitoring Program (FMMP) housed at the University of Cincinnati. ${ }^{1}$ Additional data came from primary documents about Fernald housed at the Fernald Preserve library. Other important sources of information included attendance at the Fernald Community Alliance (FCA) meeting in June 2013, as well as informal contact and conversation with former workers who function as liaisons for workers in the FMMP program.

The FCA was established as an advisory group to work with DOE and manager Fermco Fluro Daniel, in the clean-up and remediation of the Fernald site. The FCA meets regularly four times a year and consists of former Fernald workers, FRESH and other community members, environmental interests, and DOE/Fernald Preserve employees. I had made contact with this group several months prior to the meeting as a way to introduce myself, the research project, and to recruit participants for the study. I had previously worked with some of the current members of the FCA in the early 1990s on a research project involving FRESH (Sheak \& Cianciolo, 1993). Several important things transpired at the FCA meeting in June 2013. First, it became clear that the former Fernald workers looked at a study about survivors of workers who had received compensation from the EEOICPA program with skepticism. One former worker said that my project would "stir the pot" and questioned why I would want to do that. He and the other workers present indicated that Fernald was a "good place to work" and

${ }^{1}$ The FMMP was a direct result of both lawsuits. For residents, the medical monitoring program was operational from 1990 through 2008, and for workers it began in 1995 and provides medical monitoring until the worker dies (R. Wones, personal interview, October 12, 2013).

Michigan Family Review, 19(1), 51-72, 2015. DOI: 10.3998/mfr.4919087.0019.103 (C) Michigan Council on Family Relations 
"there was a great deal of camaraderie because of the nature of the work; we couldn't talk to our families so we talked to each other." They had known people who had applied for EEOICPA compensation but their claims were denied. Some had "given up" because the process was just "too complex", and that receiving compensation was "personal."

Another worker affiliated with the FMMP program who had agreed to be interviewed for my project abruptly declined the day before when I phoned him. He indicated that he was in the claims process himself and did not want to jeopardize it in any way, saying that "Washington [D.C.] runs hot and cold on the program.” One worker present at the meeting - who understood the focus of the study - cautiously said he would contact some people, which did produce one participant. The second thing that happened at the FCA meeting was the voluntary interjection and advocacy of the study by a FRESH member, who asked pointedly:

Do you have family members? Do you know how they looked at your employment at Fernald? Did they know that you probably brought contaminating clothing into your house?

The same individual went on to say "there's always been tension between workers and FRESH members." Although this helped to legitimize the study to some degree, it was a reminder of the powerful impact employment at Fernald had on workers. These interactions between individuals at the FCA meeting provide a small window into the intense feelings still surrounding what happened at Fernald that may have impacted this study.

\section{Findings}

Four major themes were identified in the analysis of the seven interviews that were conducted, as well as informal contact with individuals at the FCA meeting: 1) work as accomplishment - work as a source of psychological distress; 2) work as a form of patriotism - government betrayal of workers; 3) hardship on families; and 4) the inadequacies of social justice. The major themes that emerged from the data are discussed below.

\section{Work as Accomplishment versus Work as Psychological Distress}

Two long-time Fernald workers, pseudonyms Mr. Lesser and Mr. More, were interviewed for the study. Mr. Lesser had received EEOICPA compensation; Mr. More had applied for it but was denied. During our interviews, each one clearly showed an immense sense of pride about what had been done at Fernald, and the ingenuity it took to accomplish the work. Both were chemical engineers with master's degree training and years of experience in the industry. Mr. Lesser had been involved in nuclear weapons production during the late 1940s and early 1950s. He was employed at the Oakwood facility or "Dayton Project," in Dayton, Ohio, which was a part of the Manhattan Project. This is where he became familiar with radioactive materials, notably polonium, a particularly dangerous radioactive substance. This experience gave him "an edge" on employment credentials and he started work at Fernald in 1952, in the 
technical division of the chemical department. Mr. Lesser told me that production problems at Fernald surfaced early on. There was drum deterioration that contained uranium, dust vents that clogged, and inadequate ventilation systems. These things were viewed as challenges to be overcome and not insurmountable problems:

We improvised a great deal to make the plant work...ideas came from hourly, foremen, maintenance, technology people...I was more interested in the technology rather than the production numbers...In a typical day there were fume releases, there were fires, there were explosions, and there were process difficulties...The production foremen were pressed to keep operation going until modifications or improvements or breakdown experienced...had been fixed...It was a matter of priorities.

Mr. Lesser voiced his pride in describing the work that he had done in improving plant production. Yet, when the Fernald worker's litigation began, Mr. Lesser became a consultant on behalf of workers versus management. When asked why he made this choice, he stated:

...I felt very strongly about the role of workers and first line supervision, because they were on the firing line day in and day out. They needed someone to explain to attorneys who represented them what was in the documents they were allowed to see. And, they needed somebody to help them. I did that and I'm proud that I did that.

Mr. Lesser showed me hand calculations he had made of production records and radiation risks in Plant 9 during the plant's production years. In some cases his records showed that workers were exposed to radiation levels 600 times the allowable limit. During our interview this acknowledgement visibly upset him. He told me he was afraid that somehow he had "let [his] fellow workers down by not knowing how much they were being exposed to.” Mr. Lesser had received EEOICPA compensation because he developed multiple cancers caused by radiation exposure. He divulged that his daughter had died in her early 40s because of a brain aneurysm. She was happily married, the mother of two, and had a promising career. He wonders if radiation exposure somehow altered his reproductive system, which in turn may have led to a weakness in his own daughter's brain. His wife, who was in the same room during our interview, interjected and said to her husband, “...don't go there, don't do that to yourself.” Regrettably, he'll never know the answer on either score. What was clear in this interview, however, was how torn Mr. Lesser was between his allegiance and pride in his work and his guilt and distress about what had happened to workers.

The second long-time worker, Mr. More, started at Fernald in 1954, as a co-op student while attending the University of Cincinnati in chemical engineering. He furthered his education in the same field, working in production and then ending up in management. He consulted with the DOE about Fernald and other facilities that were dealing with "cannibalized equipment" issues and financial, technical, and community relations problems. Mr. More told me that in the 1970s there was an "almost epidemic of cancers" among Fernald workers and 
“it got very scary.” By the 1980s, studies had demonstrated a highly credible link that working at Fernald had caused certain cancers, but Mr. More had experience dealing with this cancer problem at Fernald much earlier.

By 1986, Westinghouse plant management recognized Fernald needed a "pied piper" to deal with the public relations problem it had. This was largely due to the uranium dust releases and acknowledgment of contaminated wells. Mr. More worked collaboratively with the DOE, Westinghouse, the Ohio Environmental Protection Agency, and community members to bring the facility into compliance with environmental and safety regulations. He oversaw workforce development for clean-up efforts under Fermco Fluro Daniel from 1993 to 2006. Under Mr. More's leadership clean-up efforts were completed in 2006, six years prior to the expected date of 2012. In his role as “pied piper," he noted "I was called to head up total quality management; I saw a lot of young, talented people and got a workforce for clean-up that was excellent." In relation to the EEOICPA program he stated "It's good there's compensation but Fernald requires dose reconstruction and it is not a special exposure cohort." Later in the interview Mr. More said:

It's cruel to the family survivors...they have no idea; families today are left to respond to dose reconstruction having no clue. Victims are in a weakened state - it's cruel in my book. It's a cruel thing to place on victims or families...they are just not equipped to respond to dose reconstruction.

At the same time as being confident about the good work he did at Fernald (both for the plant and the workers), the "cruelty" he experienced was distressing to say the least. What is clear in both Mr. Lesser's and Mr. More's conversations is the contradiction they felt between feeling good about their work accomplishments and witnessing the extreme health consequences for workers.

\section{Work as a Form of Patriotism versus Government Betrayal of Workers}

The massive growth in the U.S. nuclear weapons complex was legitimized as the ultimate necessity to prevent the spread of communism and avert WWIII. A significant number of workers at Fernald were WWII veterans who believed their work was a patriotic duty. They did what was expected of them and showed this by their abiding allegiance.

NLO, who managed the plant from 1951 - 1985, also emphasized a strong sense of team work and community and fostered the patriotism that Fernald workers associated with their work. Softball and bowling leagues, annual picnics, dances, and the establishment of a company credit union helped to accomplish a sense of solidarity among employees and create a "family friendly" work environment. It was also a mechanism to develop the necessary cohesion to promote allegiance as well as secrecy about the plant's production of nuclear weapons. The Atomizer, an in-house publication, regularly reported on league standings, social activities committees, worker accomplishments, and promoted carpooling. The following excerpts from The Atomizer provide examples of how 
this publication created a team environment, yet also reminded workers of the secrecy surrounding their work:

The Atomizer, January, 1954, Vol. III, No.1, p.8 - "Know Your Ps \& Qs" - "Confucius once said "What I would keep from a foe I do not tell a friend." In the modern specific application, AEC says "Tell only those who are Q cleared and need to know.”

The Atomizer, May, 1954, Vol. III, No.5, p.3 - “Loyalty, Teamwork Necessary to Plant Function,” Fernald Plant Manager, George M. Wunder stated at the Foreman's Club luncheon "the goal of plant management is that each employee knows that operation will not function to its greatest efficiency if he is not willing to work for the team."

The sad irony was that this same work environment made so many of the workers sick or die prematurely. Mr. Long, the son of a deceased worker who had received EEOICPA compensation, believed that the loyalty of Fernald workers came out of a WWII mentality, but went on to say:

You cannot sacrifice people's health. I'm 100\% for government but it should also protect us...can't put blinders on - if my country is doing something wrong it has to admit it so the wrong is not repeated...Workers should have been compensated more for what they did...there wasn't any thanks or anything. We went through the whole process and the last thing on top of all the [application] papers was a copy of the check I got.... lot of these men were WWII veterans, a lot who had 30 or more years of service to their government and their government is saying - here's what your life's worth - that's it, that's all you're getting.

Ms. Smith, one of the lawyers who was part of legal representation team for the Fernald worker's litigation and interviewed for the study agreed with Mr. Long's assessment of the situation. She indicated that most workers at Fernald were WWII, Korean, and later Vietnam vets who had a loyalty to this country and trusted the government. Yet, Ms. Smith explained, "Workers felt betrayed by both NLO and Westinghouse, and their government. Workers' believed that they would be kept safe at work.” Workers may have felt patriotic but the children and lawyers of these workers could also sense Fernald's betrayal of that patriotism.

\section{Hardship on Families, Both Then and Now}

Fernald was not designated as a "special exposure cohort” (SEC) under the EEOICPA legislation. Not having this special legal status meant that family members were required to provide documentation to prove that their spouses' or parent's cancer(s) was caused by exposure in the workplace. One survivor, Mr. Long, indicated that the process was very complicated. He learned about the EEOICPA program in 2005, through an advertisement in a local newspaper and pursued application on his own through the Portsmouth Resource Center. His dad had worked as a chemical operator from 1954 to 1969, and then again from 1973 to 1980 . He died in 1990 of multiple cancers - skin first, then throat cancer and 
prostate cancer that metastasized to the bone. Throat cancer was the diagnosis that allowed for compensation. Fifteen years after his dad's death, Mr. Long had to obtain his medical records, get documentation from former supervisors about where he worked, what he did at Fernald, and when he worked there. The application and determination process took two years from start to finish:

...they give you forms but you're getting no help. All the information I had I had to give to them...I was in the rare circumstance of working there [at Fernald] myself...I could not have told them that my dad worked in Plant 5. If I had not worked there I would've been in the dark...that's the situation for most survivors.

Mr. Long went on and said that his dad's death was "hard on my mom," and that he cared for her for nine years after his father passed away. She died before the EEOICPA legislation was enacted. Although Mr. Long has never worried about any personal health ramifications from his father's employment at Fernald, he did express concerns about his own five years of employment at Fernald from 1973 to 1978 . He worked the night transportation shift and saw things that many did not. He said:

You shouldn't sacrifice your safety for anyone...I've been away from it for 40 years and I'm still not sure I'm safe from it...if you worked there you've always got this cloud hanging over you... are you going to come up with something from working there... it's like my dad, he worked there probably five or seven years and then became sick...he had 20 years of exposure.

A second survivor, Mrs. Short, applied for compensation in 2001 for her 100-year-old mother as a surviving spouse of a worker, but was denied because rectal cancer was listed as cause of death on her father's death certificate. Had it stated lung cancer, which he had too, eligibility would not have been an issue. Mrs. Short's dad worked as a gauge set-up worker from 1951 to 1963, at which time he retired. The application and determination process has been an especially difficult one for her and her family:

My father died from cancer and that was a prerequisite for compensation... he died in 1971, and those records could not be retrieved to confirm the fact he had two primary cancers. The one we know he had in 1963 when he left the plant was lung cancer but because they [NIOSH] could not locate any of the medical documents and the doctor who treated him was deceased, they had to go by the death certificate...we had to locate records, provide worker location in the plant the best we could. We had no knowledge that he worked in the Pilot Plant where hexafluoride and thorium were - we didn't know.

For eight years Mrs. Short worked tirelessly to have Fernald designated as an SEC facility, confronting numerous bureaucratic obstacles along the way. The plant did receive SEC approval in 2012, but her father's employment may be 
outside of the designated years for coverage (1968 - 1978). Speaking about her role in applying for Fernald's SEC status, Mrs. Short continued:

I wasn't aware, basically didn't know the EEOICPA was being prepared until after the fact, so guidelines [of the law] had already been set up. It could have been better written...I think the administration of the law didn't necessarily follow guidelines it was intended; it provided an opportunity for conflict...you know I figured I don't know who else could have done it. I have a unique way of processing details...unless somebody applies [for SEC designation], they're not going to do anything unless there's somebody to buck the system.

Mrs. Short is convinced her father's exposure at Fernald caused his cancers. She also believes that her own breast cancer may have been a result of something her dad brought home while he worked there:

You can't be exposed to something for 12 years that the potential of changing your body chemistry and destroy cells is not going to have an effect on your body. One of the things that was never considered was the biochemical, the cell mutation... what affects person A may not affect person B in the same way. And that was never a factor...Unfortunately I am sharing my family history...yeah, it's pretty present, I had cancer eight years ago and I was informed it was due to some exposure I had had. I am assuming it was in my daddy's lap when he came home from work. I was five years old when he started working there [laughs].

In both interviews with family survivors, a tension in generational belief systems was evident. While their fathers believed that working at Fernald was their patriotic duty, the children were adamant about the responsibility the government and its indemnified corporate managers should bear for intentionally putting their loved ones in harms' way. EEIOCPA compensation to these family members was viewed as quid quo pro, at least from the perspective of adult children interviewed for this study. Yet, obtaining that compensation involved a very lengthy, contentious, and emotional process and only the most determined could make it through the process.

\section{Inadequate Social Justice for Families}

As is clear in the above section, participants in the above section acknowledged the limitations of the EEOICPA program to provide social justice for workers and their families. When Mr. Long received the \$150,000 U.S. Treasury check in the mail he remembers feeling like it was "a victory won in a battle." But, he went on to say that he did not believe that any monetary value could compensate for his dad's death and the work he did at Fernald. During the interview he paraphrased his wife's reaction to receiving the compensation. Employed as a court recorder when Judge Spiegel ruled in favor of the Fernald workers' lawsuit in 1994, she declared, "I'd rather have my father-in-law instead of the money." Mrs. Short, whose family had yet to receive compensation related this to larger issues of social justice: 
... [There is no social justice] until compensation is received and then it cannot replace a life...I think there were experts who made assumptions about uranium based on the limitations of their own knowledge...I've learned about how radiation works... it won't have an effect on a strong healthy person but a person with a weakened system...effects can be devastating.

When asked about whether the EEOICPA compensation could really represent social justice, Mr. More said:

I don't know. There is no compensation, no amount of money that can compensate for the illness... It may be fair and equitable assistance and a good attempt to assist with medical bills... but for workers it's more insidious because they were exposed to a continual threat over a life-time and that caused a disproportionate amount of afflictions. The law is an attempt to compensate.

He went on to say: "Dose reconstruction for Fernald workers has been a barrier for workers - the little folks who were afflicted don't get a nickel.” Mr. More concisely summarized the illusiveness and deficiencies of social justice remedies for those who incurred the most risk - workers and their families.

\section{Discussion and Conclusions}

Some noteworthy lessons have been learned through this research. Workers and family members often have divided loyalties and feel conflicted about the Fernald plant. Workers and their families do not always feel the same way about their involvement in plant production. Not only are their generational divides but also workers were prone to feeling patriotic towards Fernald and often felt like they accomplished a lot in their work there, even if they could acknowledge the health risks they and their families faced. In addition, legal compensation systems that are designed by the losing party or through a partisan political process, whether intentional or unintentional, are not designed to be user friendly. The difficulty of navigating such a system creates a double victimization for workers and family members - they are forced to deal with both the original injury and the process injury. Workers and their families are thrust into direct confrontation with governmental or corporate negligence that caused sickness or killed their loved ones. There is a haunting uneasiness about past and future health issues that may be as a result of exposure, and this uneasiness will remain unresolved. Facilitating the compensation process for workers and families is essential, and this could be done via more corporate or governmental assistance in accessing records, helping with paperwork, and expediting claims. Processes delayed amount to compensation denied. The default system should be to grant claims rather than deny them. The burden of proof should reside with the perpetrator(s) rather than the victims. 


\section{Limitations of the Study}

There were a number of limitations to this study. First, The Freedom of Information Act (FOIA) precluded accessing records of workers or their survivors who had received EEOICPA compensation because health and medical information was involved. Second, interview participants varied in their connections to Fernald and therefore were a heterogeneous group. Mr. Long was the only participant who was a survivor of a nuclear weapons worker and who had received compensation on his deceased father's behalf. Mrs. Short was also a survivor and advocating for her 100-year-old mother, but still battled the government to receive compensation at the time of the interview. Two more participants were former Fernald workers, Mr. Lesser who had received compensation, and Mr. More whose claim had been denied. Other participants were lawyers and a physician who worked with Fernald workers. The original goal was to recruit adult survivors of workers who had received compensation, but this group was difficult to identify and hard to reach, and using these inclusion criteria was a significant participant recruitment barrier. Fernald workers would be in their late 60s through 90s, and many are now deceased. Identifying the spouses or adult children of these workers was problematic, and to do so would have required significant advertisement in Cincinnati, Dayton, Hamilton, Harrison, Ohio, and Indiana newspapers. By remaining flexible and open to suggestions made by key informants, I was able to identify participants to interview for the study. This in turn created a meaningful research study and gave voice to a group whose stories might otherwise never have been heard.

Nonetheless, generalizability of the study results remain tentative.

Third, former worker skepticism of the project and the perception of the "personal" nature of receiving compensation was a hindrance to recruitment as well. There was a very explicit reason why workers or their family members had received EEOICPA compensation; it was because of an illness or death of a loved one. To come face-to-face with this reality when recruited for a study such as this is formidable.

\section{Policy Recommendations and Need for Further Research}

Thousands of former workers, family members, and communities have been impacted by the legacy of nuclear weapons production in the United States. Many workers still suffer because their illnesses remain outside of those covered by the EEOICPA legislation. As this research indicates, workers and family members eligible for compensation who are not included in SEC facilities simply may not be able to negotiate the daunting task of dose reconstruction, finding medical records of their loved one, or persevere through the long and grueling determination process. Making the application and determination process more user friendly for families is sorely needed. Additional assistance to help them with compiling the required documentation would be an important step. Conducting further research studies like this one may produce further evidence to force such changes at a macro policy level.

Another policy recommendation would be to amend the original legislation to provide medical coverage to all former workers, plus offer monetary 
compensation to family members responsible for unpaid caregiving. Although people become more susceptible to certain diseases as they age, there is little doubt that working in the nuclear weapons industry caused excessive cancer rates and has created undue burdens for family members. Furthermore, only 22 cancers are covered by the EEIOCPA program (U.S. Department of Labor, Office of Worker's Compensation, n.d.). In the case of workers who developed multiple cancers but had an uncovered one listed on their death certificate, family survivors were denied compensation. On April 14, 2015, the Toxic Exposure Research Act of 2015 (S. 901 and H.R. 1796) was introduced in Congress to address the long-term physical and emotional impact that the Iraq and Afghanistan wars have had on vets, and subsequently, their families. It represents another legislative attempt to remunerate veterans and families for the sacrifices they made in the name of patriotism, and acknowledges the generational effects that multiple toxic exposures from war related activities may have caused (Moran, 2015). Still, much more needs to be done in these areas.

Little is known about the negative health consequences that spouses and children of former weapons workers have experienced as well. Science continues to make discoveries and advance new knowledge in the areas of epigenetics, radiogenic-caused mutations, and the consequences of even small amounts of exposure to radiation. More federally funded research dollars should be devoted to this research. Evidence from the current study also suggests that there are generational differences about the perceived responsibility of government and corporate managers when loved ones are harmed or die in the course of their employment. This is an area of research that warrants further investigation.

The implications of this research go beyond the nuclear weapons industry as discussed in the opening pages of this study. History has demonstrated that the legacy of nuclear weapons production has been responsible for unparalleled suffering and long term negative consequences. Yet, nations are steadfast in their resolve that obtaining nuclear capabilities will somehow protect them. Countries who attained these capabilities long ago want to deter this proliferation, and at the same time, rush to dismantle their own arsenals. The primary social justice remedy for the harm incurred by nuclear weapons workers and their family members in the U.S. has been the legislation that created the EEOICPA program. Those employed in nuclear power production, where disasters have proven inevitable, bear a similar liability. Workers, families, and the communities in which they live should not be the collateral damage of endeavors fraught with such risk. Governments and corporations have an explicit moral obligation to right such social injustices when they occur and to prevent them from happening in the first place. 


\section{Acknowledgments}

A heartfelt thanks goes to the individuals who agreed to be interviewed for this research project. Admiration, recognition and respect is extended to the "Cold War Patriots," all of whom made a tremendous sacrifice for their country. This paper is dedicated to my father, Gus Cianciolo, who was one of them.

\section{References}

Anthes, A. (Jan/Feb, 2011). The bad daddy factor. Miller-McCune, 4(1), p.70. Retrieved from http://www.miller-mccune.com/health/the-bad-daddyfactor-25764/

Anzai, K., Ban, N., Ozawa, T., \& Tokonami, S. (2012). Fukushima Daiichi nuclear power plant accident: Facts, environmental contamination, possible biological effects, and countermeasures. Journal of Clinical Biochemical Nutrition 50(1): 2-8. doi: 10.3164/jcbn.D11-00021

Berg, B.L. (2001). Qualitative research methods for the social sciences. (4 $4^{\text {th }} \mathrm{ed}$.). Boston: Allyn \& Bacon.

Biddle, W. (2012). A field guide to radiation. New York: Penguin Group.

Bromet, E.J., Parkinson, D.K., \& Dunn, L.O. (1990). Long-term mental health consequences of the accident at Three Mile Island. International Journal of Mental Health 19(2): 48-60. Retrieved from http://www.jstor.org/stable/41350311

Brown, S.C., Schonbeck, M.F., McClure, D., Baro’n, A.E., Navidi, W.C., Byers, T., \& Ruttenberg, J. (2004). Lung cancer and internal lung doses among plutonium workers at the Rocky Flats plant: A case-control study. American Journal of Epidemiology 160: 163-172. doi: 10.1093/aje/kwh192

Cable, S., Shriver, T.E., \& Mix, T.L. (2008). Risk society and contested illness: The case of nuclear weapons workers. American Sociological Review 73: 380-401. doi: 10.1177/000312240807300302

Center for Insurance Policy and Research (2015, August 27). Nuclear liability insurance (Price-Anderson Act). National Association of Insurance Commissioners. Retrieved from http://www.naic.org/cipr_topics/topic_nuclear_liability_insurances.htm

Center for Nuclear Science and Technology Information (2005, November). The Price-Anderson Act: Background information. Le Grange park, IL: American Nuclear Society. Retrieved from www.NuclearConnect.org

Charmaz, K. (2005). Grounded theory in the $21^{\text {st }}$ century: Applications for advancing social justice studies. In N.K. Denzin \& Y.K. Lincoln (Eds.), The Sage handbook of qualitative research ( $\left.3^{\text {rd }} \mathrm{ed}.\right)$, (pp.507-535). Thousand Oaks, CA: Sage.

Charmaz, K. (2006). Constructing grounded theory: A practical guide through qualitative analysis. Thousand Oaks: CA: Sage.

Cincinnati Enquirer, 1957 (October, 5, 6, 7, 8). Employment Advertisement for Chemists, Chemical Engineers, Electrical Engineers, Metallurgists, and Metallurgical Engineers. 
Cincinnati Times Star (1951, May 7). "National Lead of Ohio wins contract with Atomic Energy Commission to operate Fernald facility."

Clausing, J. (2013, November 30). Los Alamos working to create national park. The Mining Journal, p.6A.

Cohen, S. (1994, October 9). Nuclear workers win; their health still loses: Fernald, Ohio: A judge is to hold fairness hearing Tuesday on a proposed \$20-million settlement for former employees of a uranium- processing plant. But the settlement too late for some. Los Angeles Times. Retrieved from http://articles.latimes.com/print/1994-10-09/news/mn48170_1_fernald-workers

Cold War Patriots (n.d.). http://www.coldwarpatriots.org

Creswell, J.W. (2007). Qualitative inquiry \& research design: Choosing among five approaches ( $2^{\text {nd }}$ ed.). Thousand Oaks, CA: Sage Publications.

Dawson, S.E. (1992). Navajo uranium workers and the effects of occupational illnesses: A case study. Human Organization 51(4): 389-397. doi: 10.17730/humo.51.4e02484g513501t35

Denzin, N.K., \& Lincoln, Y.S. (Eds.). (2005). The Sage handbook of qualitative research ( $3^{\text {rd }}$ ed.). Thousand Oaks, CA: Sage Publications.

Executive Order 13179 (December 7, 2000). Providing compensation to America's nuclear weapons workers. Federal Register, 65, No. 238, Monday, December 11, 2000.

Flynn, M. (2001). A debt long overdue: Nuclear weapons work made people sick - at last, workers may be compensated. Bulletin of the Atomic Scientists 57(4): 38-48. doi: 10.2968/057004011

Gallagher, C. (1993). American ground zero: The secret nuclear war. New York: Random House.

Greene, G. (1999). The woman who knew too much: Alice Stewart and the secrets of radiation. Ann Arbor: University of Michigan Press.

Hilton, T. \& DeJong, C. (2010). Homeless in God's country: Coping strategies and felt experiences of the rural homeless. Journal of Ethnographic \& Qualitative Research 5: 12-30.

Interlandi, J. (2013). Code Breaker: Michael Skinner, Natural Sciences. Smithsonian: 2013 American Ingenuity Awards 44(8): 78-82.

Kiernan, D. (2013). The girls of the atomic city: The untold story of the women who helped win World War II. New York, NY: Touchstone.

Maag, C. (2006, September 20). "Nuclear site nears end of its conversion to a park.” The New York Times. Retrieved from http://www.nytimes.com

Makhijani, A. (2001). The burden of proof. Bulletin of Atomic Scientists 57(4): 49-54. doi: 10/2968/57004012

Mason, M. (2010). Sample size and saturation in $\mathrm{PhD}$ studies using qualitative samples. FQS 11(3): 1-14. Retrieved from http://www.qualitativeresearch.net/index.php/fqs/article/view/1428/3027

Mix, T.L., \& Shriver, T.E. (2007). Neighbors, nuisances and noxious releases: Community conflict and environmental hazards in the atomic city. Social Science Journal, 44, 630-644. doi:10.1016/j.soscij.2007.10.004 
Moran, J. (April 14, 2015). Sens. Moran, Blumenthal and Reps. Benishek, Honda introduce Toxic Exposure Research Act of 2015. Retrieved from http://moran.senate.gov/

Monk, R. (2012). Robert Oppenheimer: A life inside the center. New York: Anchor Books.

Nesbit, T. (2014). The wives of Los Alamos. New York: Bloomsbury.

New York Times (1994, July 27). Energy Dept. settles lawsuit with workers. Retrieved from http://www.nytimes.com

Nuclear Energy Institute (2014, October). Lessons from the 1979 accident at Three Mile Island [Fact Sheet]. Retrieved from www.nei.org

O’Farrell, P. (2006, July 23). "Final chapter for Fernald: Uranium plant goes from A-bomb cog to toxic site, and now to a nature park.” Cincinnati Enquirer, pp. 1-10. Retrieved from http://news.cincinnati.com/article/20060723/NEWS01/607230358/Finalchapter-Fernald

Office of Legacy Management, U.S. Department of Energy. "Fernald Closure Project: The end of secrecy.” Retrieved from http://www.lm.doe.gov/land/sites/oh/fernald_orig/50th/secr.htm

Physicians for Social Responsibility (n.d.). Radiation and public health factsheet. Retrieved from http://www.psr.org/resources/radiation-and-publichealth.pdf

Puddephatt, A.J. (2006). An interview with Kathy Charmaz: On constructing grounded theory. Qualitative Sociology Review 2(3). Retrieved from http://www.qualitativesociologyreview.org/ENG/archive_eng.php

Rawls, J. (1999). A theory of justice (Rev. ed.). Cambridge, MA: Harvard University Press.

Roe, S. (1999, March 28, 29, 30, 31; April 1, 2, 17, 23; June 9, 19; July 16; August 19; October, 6, 9; November 18; December 2, 29; 2000, February 18). "Deadly alliance: How government and industry chose weapons over workers.” The Toledo Blade. Retrieved from http://www.toledoblade.com/deadly-alliance

Roff, S.R. (1996). The dark side of the nuclear family. New Statesman. 128.4419 (Jan. 15, 1999): p.28. Retrieved from http://go,galegroup.com/ps/i.do?\&id=GALE\%7CA54157806\&v=2.1\&u $=$ lom_nmichu\&lit_r\&p_LitRC\&sw=w

Roman, E., Doyle, P., Maconochie, N., Davies, G., Smith, P.G., \& Beral, V. (1999). Cancer in children of nuclear industry employees: Report on children under 25 years from nuclear industry family study. British Medical Journal 318 (7196): 1443-1450. doi: http://dx.doi.org/10.1136/bmj.318.7196.1443

Samet, J.M., \& Chanson, D. (March 9, 2015). Fukushima Daiichi power plant disaster: How many people were affected? 2015 Report. (pp.1-51), University of Southern California, Department of Preventive Medicine. Schettler, T. (October, 2011). Environmental exposures, infertility, and related reproductive disorders: An update. The Collaborative on Health and the 
Environment. Pp. 1-22. Retrieved from:

http://www.healthandenvironment.org/infertility/peer_reviewed

Soble, J. (2015, October 20). “Japan to pay cancer bills for Fukushima worker.” The New York Times. Retrieved from http://www.nytimes.com/2015/10/21/world/asia/japan-cancerfukushima-nuclear-plant-compens.

Sheak, R. \& Cianciolo, P. (1993). Notes on nuclear weapons plants and their neighbors: The case of Fernald. Research in Social Problems and Public Policy 5: 97-122.

Thorp, N. (2011, May 11). Uranium metal from Fernald, OH. Washington Nuclear Museum and Educational Center. Retrieved from http://toxipedia.org/display/wanmec/Uranium+metal+from+Fernald,+OH

University of Cincinnati Academic Health Center (2012, November 12). Uranium exposure linked to increased lupus rate. Health News. Retrieved from http://healthnews.uc.edu/news/?/21316/

U.S. Department of Labor (n.d.). Title 42-The Public Health and Welfare, Chapter 84-Department of Energy, Subchapter XVI-Energy Employees Occupational Illness Compensation Program. Retrieved from http://www.dol.gov/owcp/energy/regs/compliance/law/EEOICPAALL.ht $\mathrm{m}$

U.S. Department of Labor, Office of Workers’ Compensation Programs (n.d.). Division of Energy Employees Occupational Illness Compensation (DEEOIC). Retrieved from http://www.dol.gov/owcp/energy/

U.S. Department of Labor, Office of Worker's Compensation Programs (2012a, September 23). EEOICP Program Statistics. Retrieved from http://www.dol.gov/owcp/energy/regs/compliance/weeklystats.htm U.S. Department of Labor, Office of Worker's Compensation Programs. (2012b, August 8). News Release - US Department of Labor notifies former Feed Materials Production Center employees of inclusion in new EEOICPA Special Exposure Cohort. Retrieved from http://www.dol.gov/opa/media/press/OWCP/OWCP20121537.htm

U.S. Environmental Protection Agency (June, 2010). Fernald Preserve: Success Story. EPA Region 5 Superfund Redevelopment Initiative.

Wald, M.L. (1989, February 25). "New radiation study planned in Ohio.” The New York Times, p.7.

Warrick, J. (1999, September 21). "Radiation risks long concealed: Paducah plant memos show fear of public outcry." The Washington Post, A01.

Wesolowski, K. (2015). To have or not to have a child? Perceived constraints on childbearing in a lowest-low fertility context. Population, Space and Place 21: 86-101. doi: 10.1002/psp.1811

Welsome, E. (2000). The plutonium files. New York: Random House.

Willette, A. (1990, July 4). "Fernald cost still rising: Cleanup will be more than $\$ 2$ billion, DOE says”. Cincinnati Enquirer, p. A-1.

Wones, R., Pinney, S.M., Buckholz, J.M., Deck-Tebbe, C., Freyberg, R., and Pescoe, A. (2009). Medical monitoring: A beneficial remedy for residents 
living near an environmental hazard site. Journal of Occupational and Environmental Medicine 51(12): 1374-83. doi: 10.1097/JOM.oB013e3181c558f1

World Health Organization (April, 2006). Ionizing radiation: Health effects of the Chernobyl accident: An overview. Retrieved from http://www.who.int/ionizing_radiation/chernobyl/backgrounder/en/ 